\title{
A new vertebrate fossil-bearing layer in the Rhætelv Formation (Kap Stewart Group) of central East Greenland: evidence of a Hettangian marine incursion into the continental Jameson Land Basin
}

\author{
LARS B. CLEMMENSEN (D, SOFIE LINDSTRÖM (D), OCTÁVIO MATEUS @D, MALTE MAU (D), \\ JESPER MILÀN (10) AND DENNIS V. KENT (1)
}

\section{LETHAIA}

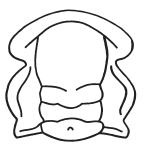

\begin{abstract}
Clemmensen, L. B., Lindström, S., Mateus, O., Mau, M., Milàn, J., \& Kent, D. V. 2021: A new vertebrate fossil-bearing layer in the Rhætelv Formation (Kap Stewart Group) of central East Greenland: evidence of a Hettangian marine incursion into the continental Jameson Land Basin. Lethaia, https://doi.org/10.1111/let.12449.

The Kap Stewart Group (Rhaetian-Sinemurian, Triassic-Early Jurassic) of the Jameson Land Basin in central East Greenland has traditionally been regarded as a strictly continental unit with delta and perennial lake sediments. New finds of plesiosaur bone remain in a thin storm deposited sandstone bed in the middle part of the Rhætelv Formation of the Kap Stewart Group, however, indicates a likely period of marine influence. At the study area at the eastern margin of the basin, the Rhætelv Formation is 300-m thick and overlies unconformably the Norian Fleming Fjord Group. The bonebearing sandstone occurs $190 \mathrm{~m}$ above the base of the group and is closely associated with black laminated mudstones; palynological investigation of three samples from these mudstones indicates that they are of a younger Hettangian age. The Hettangian was a relatively short stage (201.3-199.5 Ma) and elsewhere characterized by two episodes of sea-level highstands. Assuming that the marine incursion in the Jameson land Basin evidenced by the plesiosaur fossil remains took place during the youngest of these sea-level highstands, the bone-bearing bed of the Rhætelv Formation can be dated to $200 \mathrm{Ma}$ and thereby gives the first numerical age constraint of this hitherto poorly dated succession. $\square$ Hettangian, Jameson Land Basin, Kap Stewart Group, marine incursion, plesiosaur.
\end{abstract}

\begin{abstract}
Lars B. Clemmensen [larsc@ign.ku.dk],Department of Geosciences and Natural Resource Management, University of Copenhagen, Øster Voldgade 10 Copenhagen $K$ DK-1350, Denmark; Sofie Lindström [sli@geus.dk], GEUS; Geological Survey of Denmark and Greenland, Øster Voldagde 10 Copenhagen K DK-1350, Denmark; Octávio Mateus [omateus@fct.unl.pt], GEOBIOTEC, Departamento de Ciências da Terra, FCTUNL Faculdade de Ciências e Tecnologia, Universidade Nova de Lisboa, Campus FCT Caparica 2829-516, Portugal; Octávio Mateus [omateus@fct.unl.pt], Museu da Lourinhã, R. Joao Louis de Moura 95, 2530-158 Lourinhã, Portugal; Malte Mau [malm@ign.ku.dk], Department of Geosciences and Natural Resource Management, University of Copenhagen, Øster Voldgade 10 Copenhagen K DK-1350, Denmark; Jesper Milàn [jesperm@oesm.dk], Geomuseum Faxe, Østsjallands Museum, Rådhusvej 2 Faxe DK-4640, Denmark; Dennis V. Kent [dvk@ldeo.columbia.edu], Lamont - Doherty Earth Observatory, Palisades, NY 10968, USA; Dennis V. Kent [dvk@ldeo.columbia.edu], Earth and Planetary Sciences, Rutgers University, Piscataway, NJ 08854, USA; manuscript received on 20/04/2021; manuscript accepted on 6/08/2021.
\end{abstract}

The Kap Stewart Group (originally defined as the Kap Stewart Formation by Surlyk et al. 1973) of the Jameson Land Basin in central East Greenland (Fig. 1) forms a thick succession of interbedded black mudstones and greyish sheet sandstones in large parts of the basin; it is dated to the RhaetianSinemurian (Dam \& Surlyk 1993; Surlyk 2003; Surlyk et al. 2021). It is divided into the Innakajik and Primulaelv formations in the southernmost part of the basin (type area) and the Rhætelv Formation in the northern and largest part of the basin (Surlyk 2003; Surlyk et al. 2021). Early work on this unit was concentrated on the rich plant-bearing layers in the southernmost part of the basin along Hurry Inlet (see Petersen \& Lund 1980 for detailed information on the early history of investigation). Classical palaeobotanical studies (Harris1937 and references therein) have over the last decades been supported by multiple studies on changes in palaeobotany and palynology across the Triassic-Jurassic boundary of the Astartekløft section (McElwain et al. 1999; Hesselbo et al. 2002; McElwain et al. 2007; Belcher et al. 2010; Steinthorsdottir et al. 2011, 2018; Mander et al. 2013). Studies of stomatal proxies on fossil leaves 
from different plant groups suggest extremely elevated atmospheric $\mathrm{CO}_{2}$ concentrations at the Triassic-Jurassic boundary (Steinthorsdottir et al. 2012 and references herein). The sediments in the southernmost part of the basin were interpreted as limnic (Petersen \& Lund 1980) or as alluvial plain sediments overlain by delta plain deposits (Dam \& Surlyk 1992, 1993).

Less attention was given to the depositional environments in the northernmost part of the basin (the Rhætelv Formation). However, Surlyk et al. (1973) gave a brief description of sediments also from this part of the basin. According to them, the sediments were deposited in the nonmarine parts of large deltas and rivers perhaps with brackish-marine intercalations in the northwestern part of the basin. Clemmensen (1976) interpreted the sediments in the northernmost part of the basin as deltaic and saw evidence of tidal influence. Later work by Dam \& Surlyk (1992, 1993), however, did not find supporting evidence for marine influence and the sediments were interpreted as formed in a land-locked basin with fluvial and deltaic sediments at the basin margin and deep lake sediments in the basin centre.

Marine fossils have not been discovered in the Kap Stewart Group until recently, when Milàn et al. (2012) and Hansen et al. (2016) described a single shark tooth (the neoselachian shark Rhomphaiodon minor, a strictly marine species) from black (supposedly) lacustrine mudstones at the base of the Kap Stewart Group near 'Track Mountain' at the eastern margin of the basin (Fig. 1). Marzola et al. (2018) reported bone remains of a marine plesiosaur from
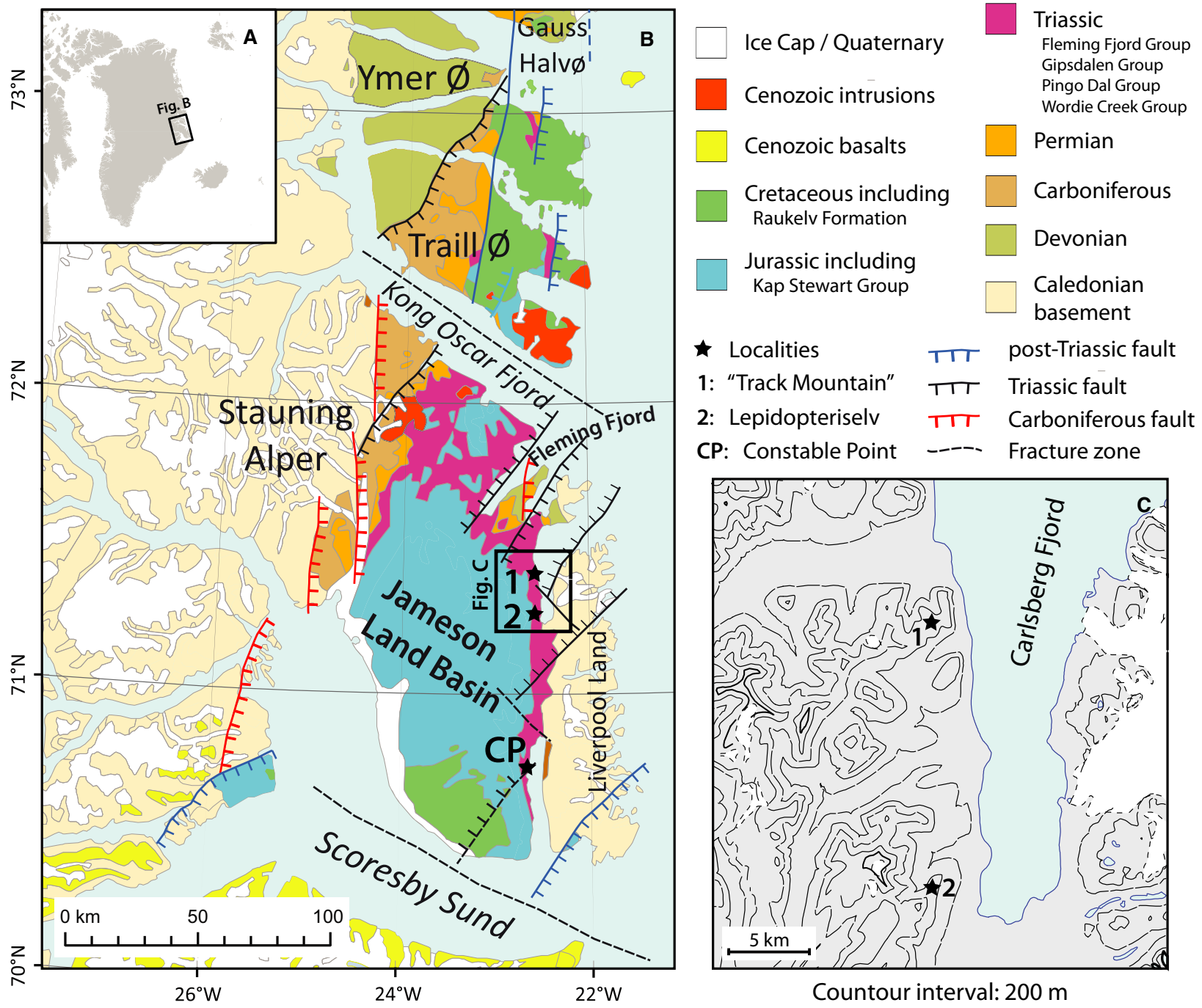

Fig. 1. Location map of the Jameson Land Basin in central East Greenland. Studied sections are indicated. Main section is at Lepidopterislev; here about $300 \mathrm{~m}$ of the Rhætelv Formation of the Kap Stewart Group is exposed. Insert map showing the location of the sections at Lepidopteriselv and immediately west of 'Track Mountain'. 
the middle part of this group at Lepidopterislev, also at the eastern margin of the basin (Fig. 1).

In this paper, we aim to place the new fossil find of plesiosaur bone remains at the Lepidopteriselv section in a chronostratigraphical framework, interpret their depositional setting and discuss their palaeoenvironmental implications in relation to Early Jurassic sea-level variation (Surlyk, 1990; Hardenbol et al. 1998; Haq 2017).

\section{Geological setting}

The Kap Stewart Group contains the Triassic-Jurassic boundary and is thus at least Rhaetian-Hettangian in age (Dam \& Surlyk 1992, 1993; Surlyk 2003; Surlyk et al. 2021). In the southern part of the basin along Hurry Inlet, the group has a thickness of about 175-m thick and encompasses the Innakajik and Primulaelv formations (Surlyk 2003; Surlyk et al. 2021). In the study area to the northeast at Lepidopteriselv and nearby localities Kap Stewart Group sediments are restricted to the Rhætelv Formation, attaining a thickness of about $300 \mathrm{~m}$ (Dam \& Surlyk 1993; Surlyk 2003). Along Hurry Inlet, the TriassicJurassic boundary is situated about $50 \mathrm{~m}$ above the base of the group (McElwain et al. 1999). However, in the northern part of the basin including the study area, the succession is too poorly dated to allow a clear definition of the Triassic-Jurassic boundary.

The Kap Stewart Group overlies a 350-m-thick Late Triassic (Norian) succession of continental (lacustrine and fluvial) deposits in the Fleming Fjord Group (Clemmensen et al. 2020; Kent \& Clemmensen 2021). At the study area at Lepidopteriselv (Figs 1,2), an erosional boundary separates the Rhætelv Formation from the underlying Ørsted Dal Formation of the Fleming Fjord Group (Clemmensen et al. 2020), and new magnostratigraphical work (Kent \& Clemmensen 2021) suggests that this unconformity could have a duration of $8 \mathrm{Myr}$. Although the Rhætelv Formation overlies the Fleming Fjord Group without visible discontinuity at most other sites in the northern part of the basin a hiatus must also be present at these localities.

Dam \& Surlyk (1993) interpreted the Kap Stewart Group sediments to have formed in and around a large wave-and storm-dominated anoxic lake. Coarse-grained sediment was transported to the lake from eastern, western and northern source areas and formed large delta systems. The Kap Stewart lake system displays several short-term lake-level fluctuations many of them probably related to astronomically controlled climate change, while long-period cycles in the Kap Stewart Group were thought to record eustatic sea-level variation in the Rhaetian, Hettangian and Sinemurian (Dam \& Surlyk 1992, 1993). According to this interpretation, the lake system could have had a duration of up to 15$20 \mathrm{Myr}$ before it was transgressed by the sea at the Sinemurian-Pliensbachian transition (Dam \& Surlyk 1992, 1993, 1998; Surlyk 2003).

\section{Material and methods}

In 2016, bone remains of a plesiosaur were found in scree from the Rhætelv Formation at Lepidopteriselv (Marzola et al. 2018). It was possible to locate these bone remains in a thin sandstone horizon in the middle part of the Rhætelv Formation at the adjacent mountain ridge (Fig. 3; $71^{\circ} 15.761^{\prime} \mathrm{N}, 22^{\circ} 34.287^{\prime} \mathrm{W}$ ). In 2018, new examination of this sandstone bed revealed a few more plesiosaur bones as well remains of hybodontid sharks, and a mammal tooth was found in a very thin sandstone interval with burrows immediately above the bone bed. All fossils in this study are part of the collection of the Natural History Museum of Denmark (NHMD for vertebrates). A facies analysis was carried out in the section spanning the bone-bearing bed and three samples of black mudstones were collected for palynological investigation. The three samples were processed according to standard palynological preparation techniques at the Palynological Laboratory at GEUS in Copenhagen. The samples were digested in hydrochloric and hydrofluoric acids in order to remove carbonate and silicate minerals. The organic residues were mildly oxidized in $\mathrm{KOH}$, and filtered on $11 \mu \mathrm{m}$ mesh filters to remove finely particulate amorphous organic matter. Strew slides were prepared after each preparation step, including two to three additional slides after the final step, and mounted in glycerine gel. A quantitative analysis based on a count of 300 specimens from each sample was carried out on the two of the samples that contained abundant palynomorphs. The third sample only yielded few palynomorphs and was only scanned for identifiable taxa, but no quantitative assessment was performed (Table 1).

\section{The vertebrate fossil-bearing bed}

\section{Description}

The Rhætelv Formation was studied at a mountain ridge near Lepidopterielv (Figs 1, 3). The lowermost $185 \mathrm{~m}$ of the formation is nearly completely covered 


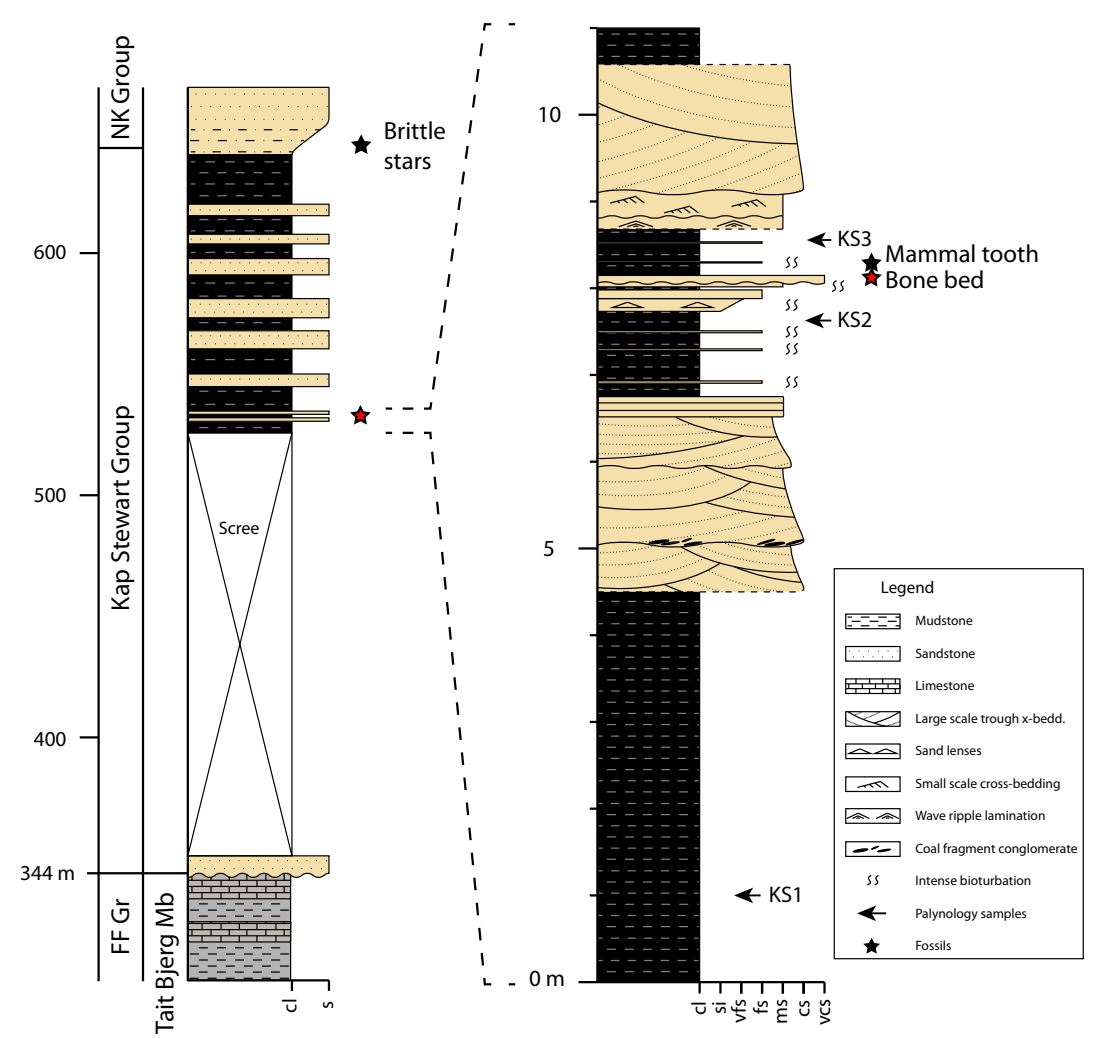

Fig. 2. Simplified stratigraphical section of the Rhætelv Formation (Kap Stewart Group) at Lepidopteriselev (Fig. 1), and sedimentary log of the middle part of the formation with the bone-bearing bed. The Rhætelv Formation is exposed on a mountain ridge between 344 and $633 \mathrm{~m}$ above present sea level.

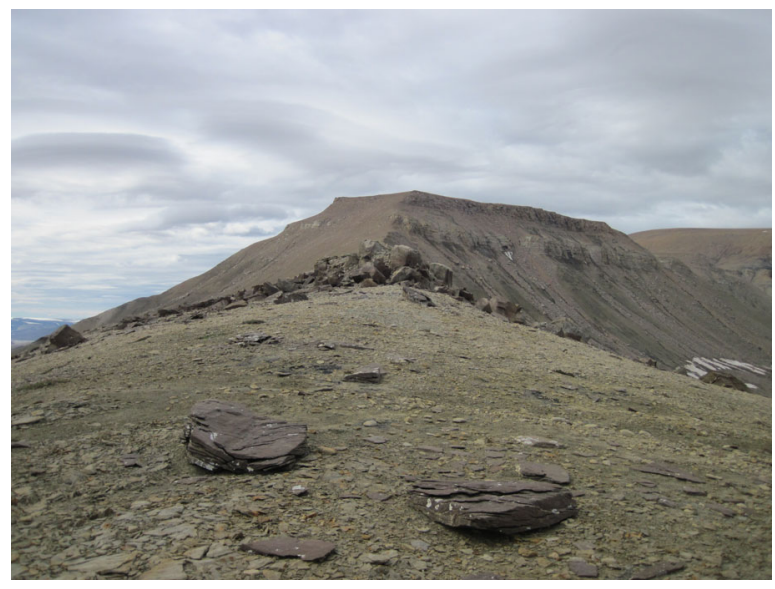

Fig. 3. The middle part of the Rhætelv Formation (Kap Stewart Group) at Lepidopteriselv. Poorly exposed, fine-grained sediments including 'paper shales' at the base of the section are overlain by a strongly disintegrated distributary channel sandstone with an approximate thickness of $2 \mathrm{~m}$. The bone-bearing bed is situated immediately above the sandstone. At the top of the mountain are cliff-forming sandstones in the Neill Klinter Group.

by scree and the uppermost part is apart from few sections not exposed to a degree that enables detailed sedimentological studies. However, at one site between 185 and $200 \mathrm{~m}$ above the base of the formation good exposures are present. In this interval, the bone-bearing bed is situated. About $300 \mathrm{~m}$ above the base of the formation, sediments with imprints of brittle stars are seen on top of black mudstones (Fig. 2). Dam \& Surlyk (1998) write that fossiliferous sandstones of the Neill Klinter Group overlie black mudstones (paper shales) of the Rhætelv Formation. In agreement with these authors, we therefore include the sediments with brittle star imprints in the basal part of the Neill Klinter Group (Fig. 2).

The bone-bearing bed forms part of succession with units of black laminated mudstones ('paper shales') and 1.5- to 3-m-thick sandstone bodies composed of coarse-grained sand with large-scale troughformed cross bedding and numerous transported plant and coal fragments (Figs 2, 3). The bonebearing bed is a thin sandstone about $25-\mathrm{cm}$ thick, over- and underlain by black laminated mudstone. It is a medium- to coarse-grained sandstone with even lamination and some intraformational black wood fragments at the base in association with the bone fragments. The closely associated black mudstones contain several thin (1- to $2-\mathrm{cm}$ thick) sandstone intervals frequently with burrows. One of these burrow fills contained a mammal tooth. The tooth 
Table 1. Spores and pollen in three samples from the middle part of the Rhætelv Formation (Kap Stewart Group), Lepidopteriselv, East Greenland.

\begin{tabular}{|c|c|c|c|c|}
\hline Taxa & Reworked, questionable & KS 1 & KS 2 & KS 3 \\
\hline $\begin{array}{l}\text { Spores and pollen } \\
\text { Alisporites radialis }\end{array}$ & & $1.00 \mathrm{~m}$ & $7.60 \mathrm{~m}$ & $\begin{array}{l}8.60 \mathrm{~m} \\
2\end{array}$ \\
\hline Alisporites robustus & & 1 & $\mathrm{X}$ & 10 \\
\hline Alisporites thomasii & & & & 1 \\
\hline Aratrisporites minimus & & & & 2 \\
\hline Aratrisporites spp. & & & & 1 \\
\hline Baculatisporites comaumensis & & $\mathrm{X}$ & & \\
\hline Baculatisporites oppressus & & $\mathrm{X}$ & & \\
\hline Bisaccate, unidentifiable & & 15 & $\mathrm{X}$ & 10 \\
\hline Calamospora tener & & 10 & $\mathrm{X}$ & \\
\hline Chasmatosporites apertus & & 5 & $\mathrm{X}$ & 7 \\
\hline Chasmatosporites hians & & 10 & $\mathrm{X}$ & 17 \\
\hline Chordasporites spp. & & & & 1 \\
\hline Classopollis classoides & & 1 & $\mathrm{X}$ & $\mathrm{X}$ \\
\hline Classopollis meyerianus & & 4 & $\mathrm{X}$ & 10 \\
\hline Conbaculatisporites spinosus & & 7 & $\mathrm{X}$ & $\mathrm{X}$ \\
\hline Cordaitina spp. & $\mathrm{R}$ & & & 1 \\
\hline Geopollis zwolinkai & & 1 & & $\mathrm{X}$ \\
\hline Cyclogranisporites sp. & & & & 1 \\
\hline Deltoidospora minor & & 15 & $\mathrm{X}$ & 8 \\
\hline Deltoidospora toralis & & 46 & $\mathrm{X}$ & 24 \\
\hline Eucommiidites minor & & 1 & & \\
\hline Eucommidiites granulosus & & & & $\mathrm{X}$ \\
\hline Eucommiidites troedssonii & & 3 & & 3 \\
\hline Granulatisporites sp. & & 2 & & \\
\hline Granuloperculatipollis rudis & & 2 & & \\
\hline Kraeuselisporites reissingerii & & & & 1 \\
\hline Laevigatosporites spp. & & 1 & & \\
\hline Lophotriletes spp. & & 1 & & \\
\hline Lueckisporites virkkiae & $\mathrm{R}$ & & & $\mathrm{X}$ \\
\hline Lunatisporites sp. & $\mathrm{R}$ & $\mathrm{X}$ & & $\mathrm{X}$ \\
\hline Marattisporites scabratus & & 40 & $\mathrm{X}$ & 4 \\
\hline Monosulcites sp. & & & & 1 \\
\hline Monosulcites minimus & & 8 & $\mathrm{X}$ & 4 \\
\hline Monosulcites punctatus & & 3 & $\mathrm{X}$ & 8 \\
\hline Osmundacidites wellmannii & & 25 & $\mathrm{X}$ & 1 \\
\hline Ovalipollis ovalis & ?R & & & 1 \\
\hline Perinopollenites elatoides & & 18 & $\mathrm{X}$ & 76 \\
\hline Pinuspollenites minimus & & 1 & $\mathrm{X}$ & 35 \\
\hline Platysaccus sp. & & & & 1 \\
\hline Podosporites amicus & $\mathrm{R}$ & & & 1 \\
\hline Punctatisporites globosus & & 3 & $\mathrm{X}$ & 4 \\
\hline Quadraeculina anellaeformis & & & $\mathrm{X}$ & 4 \\
\hline Retisulcites perforatus & & & & 1 \\
\hline Skarbysporites crassexina & & & & $\mathrm{X}$ \\
\hline Stereisporites aulosenensis & & & $\mathrm{X}$ & \\
\hline Stereisporites stereoides & & & & $\mathrm{X}$ \\
\hline Stratella seebergensis & & 1 & & \\
\hline Trachysporites asper & & 5 & $\mathrm{X}$ & 2 \\
\hline Trachysporites fuscus & & $\mathrm{X}$ & & 1 \\
\hline Vitreisporites pallidus & & 26 & $\mathrm{X}$ & 4 \\
\hline Vittatina spp. & $\mathrm{R}$ & & & \\
\hline Sum of spores and pollen & & 266 & & 248 \\
\hline Unidentifiable palynomorphs & & 34 & & 14 \\
\hline Aquatic palynomorphs & & & & \\
\hline Dinoflagellate cysts, unidentified & ? & & & 2 \\
\hline 'Rotundus granulatus' & & & $\mathrm{X}$ & 36 \\
\hline Botryococcus braunii & & & $\mathrm{X}$ & \\
\hline Sum of aquatic palynomorphs & & 0 & 0 & 38 \\
\hline
\end{tabular}

tentatively assigned to a docodont mammal will be the topic of a separate study.

Vertebrate fossils in the bone-bearing bed were found mostly in the form of isolated, broken bone fragments. Two dorsal vertebrae (Fig. 4A, B) and one dorsal rib (Fig. 4C), show clear plesiosaur affinities in having amphicoelous centra, paired ventral nutritive foramina in the centrum, unfused neurocentral sutures and single-headed ribs. The diameter of the centra is $2 \mathrm{~cm}$ indicating a small-sized individual 


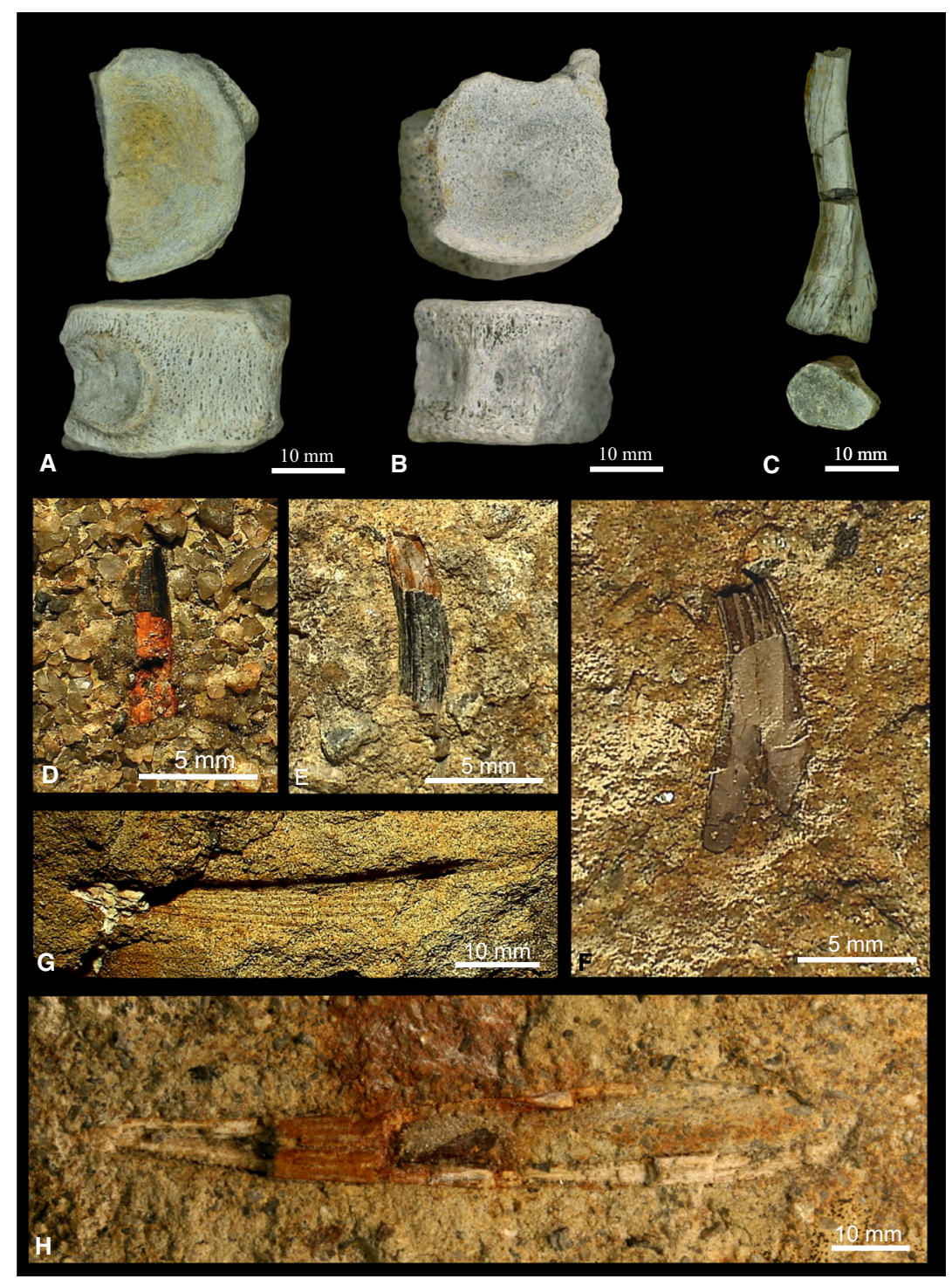

Fig. 4. Vertebrate fossils from the Rhætelv Formation (Kap Steward Group). A, B, plesiosaurian vertebrae centre (NHMD 74795 and 74796. C, plesiosaurian dorsal rib (NHMD 74797). D-F, plesiosaurian teeth (NHMD 872815-872817). G, H, partly preserved hybodontid fin spines of different sizes (NHMD 872818 and 872819).

(Milàn et al. 2016, Marzola et al. 2018). In addition to the skeletal fragments, three plesiosaur teeth were found in the same unit (Fig. 4D-F). The teeth are all incomplete and relatively small, with sizes of the fragments from 5 to $9 \mathrm{~mm}$, and an estimated total length of up to $18 \mathrm{~mm}$. The teeth are curved, cylindrical in cross-section, and have longitudinal striations in the enamel. Hybodontid sharks are represented by several partly preserved fin spines ranging in lengths from 54 to $114 \mathrm{~mm}$ (Fig. 4G, H).

\section{Interpretation}

The coarse-grained sandstone bodies resemble the distributary channel deposits of Dam \& Surlyk (1992, 1993), and are interpreted to record clastic input to delta systems along the shores of the lake/lagoon. The laminated black mudstones ('paper shales') seen at the base of the succession (Fig. 2) are identical to the open lacustrine mudstones of Dam \& Surlyk (1993). The mudstones closely associated with the bone-bearing bed are also black and laminated and of paper shale appearance, but they contain a number of very thin sandstone layers (1- to $2-\mathrm{cm}$ thick) with numerous large burrows; they could also represent open lacustrine/lagoonal deposits or alternatively they could represent sediments from a large interdistributary bay. The main bone-bearing sandstone has no apparent facies analogue in Dam \& Surlyk (1992, 1993), but it is here interpreted to record an inundation event that brought in sand and bone remains to the interdistributary bay from delta front areas. 

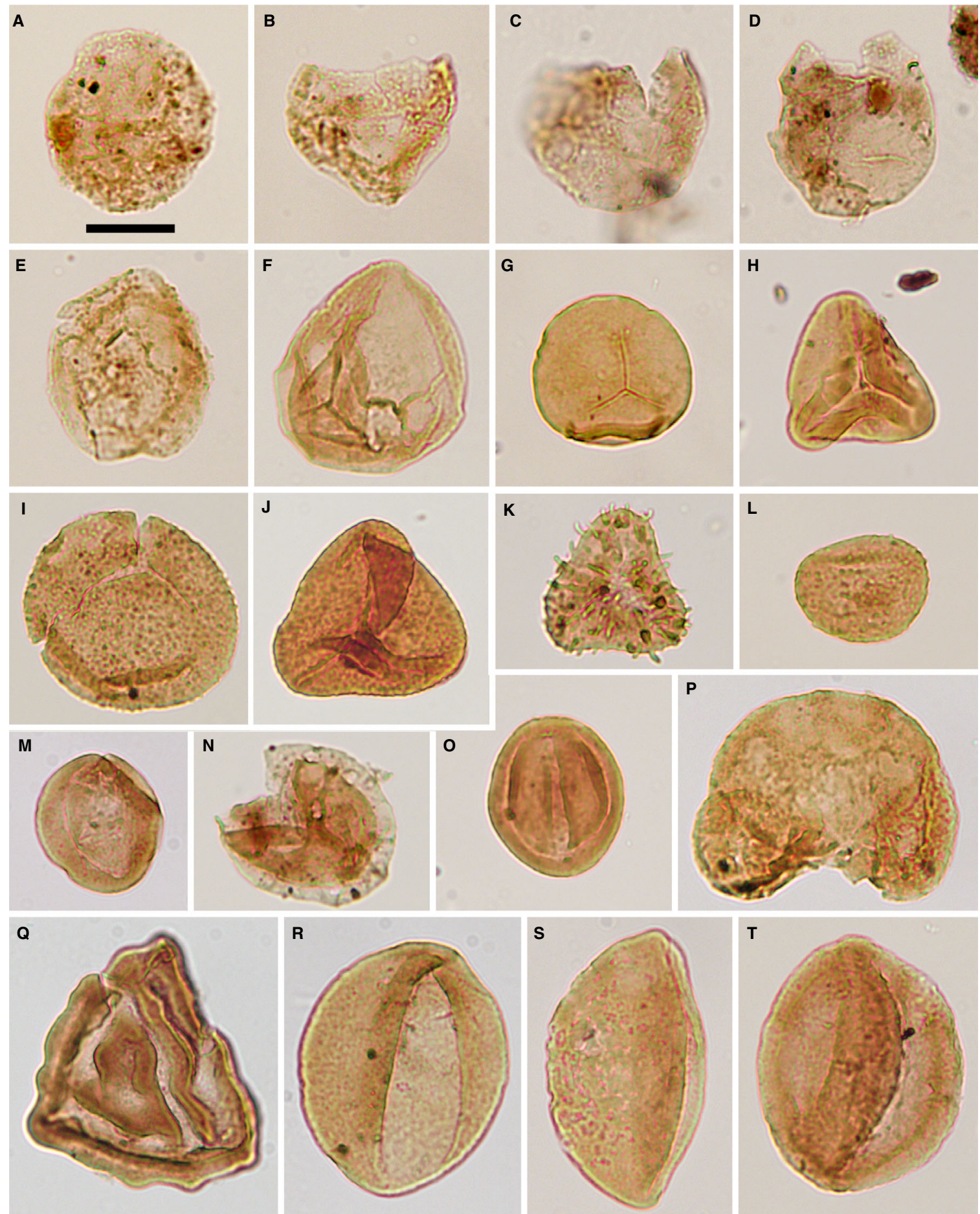

Fig. 5. Selected spores, pollen and dinoflagellate cysts from the middle Rhætelv Formation. All specimens are photographed at the same magnification; scale bar is $20 \mu \mathrm{m}$. A, 'Rotundus granulatus', a putative dinoflagellate cyst originally noted by Koppelhus \& Nielsen (1994). KS-3: 6, N52/3. B, dinoflagellate cyst with similar ornamentation as in (a), but displaying weak paratabulation. KS-3: 6, E39/2. C, dinoflagellate cyst with similar ornamentation as in (a) and (b) but displaying clear paratabulation on parts of the cyst. KS-3: 7, O37/3. D, dinoflagellate cyst with less ornamentation than in (a)-(c), but with evident epicystal paratabulation. KS-3: 7, M47/3. E, specimen of 'Rotundus granulatus', possibly displaying weak paratabulation. KS-3: 6, W50/2. F, Calamospora tener. KS-3: 6, T31/2. G, Punctatisporites globosus. KS-3: 7, F25/4. H, Deltoidospora toralis. KS-1: 8, H55/4. I, Osmundacidites wellmanii. KS-3: 6, J56/4. J, Trachysporites asper. KS-1: 8, L38/4. K, Conbaculatisporites spinosus. KS-3: 6, G36/2. L, Marattisporites scabratus. KS-3: 6, N39/4. M, Classopollis meyerianus. KS-3: 7, V45/1. N, Perinopollenites elatoides. KS-3: 6, C39/4. O, Eucommiidites troedsonii with a circumpolar furrow similar to Classopollis. KS-3: 6, N53/3. P, Pinuspollenites minimus. KS-3: 7, V30/4. Q, Striatella seebergensis. KS-3: 7, U58/3. R, Chasmatosporites hians. KS-3: 7, V47/4. S, Monosulcites punctatus. KS-3: 7, V32/2. T, Quadraeculina anellaeformis. KS-3: 6, T44/3. 


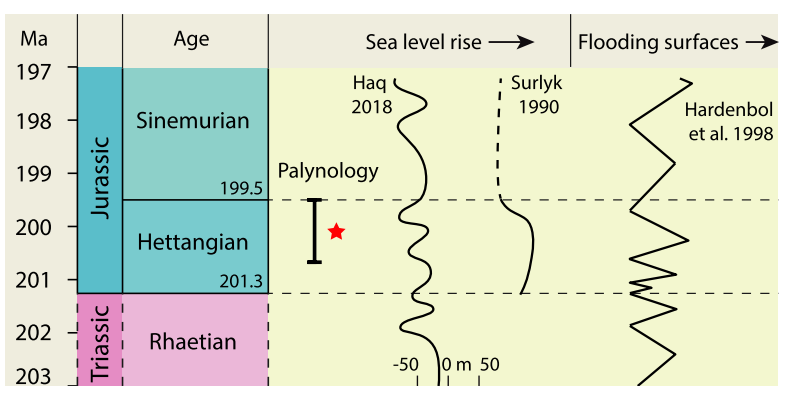

Fig. 6. Age interpretation of the 10-m-thick study section in the middle part of the Rhætelv Formation, (Kap Stewart Group), Lepidopteriselv, Jameson Land Basin. The likely age range of the succession given by palaynological data (Palynology) is shown by a vertical bar, while the star shows a likely correlation of the marine influenced succession with the second Hettangian highstand in Haq (2017). Ages given for the Hettangian are from Kent et al. (2017). The discontinuous lines of the Rhaetian indicate that deposits of this age are not known with certainty in the study area where the Rhætelv Formation overlies the Norian Fleming Fjord Group unconformably.

\section{Palynological data}

Black mudstones above and below the bone bed were sampled for palynological investigation. Sample KS1 was taken $7 \mathrm{~m}$ below the bone bed $(1.0 \mathrm{~m}$ height in the measured section), sample KS2 was taken $0.5 \mathrm{~m}$ below the bone bed, while sample KS3 was taken $0.5 \mathrm{~m}$ above the bone bed $(8.60 \mathrm{~m}$ in the section) (Fig. 2). The lowermost and uppermost samples contained relatively well-preserved assemblages dominated by spores and pollen (Fig. 5). The middle sample was dominated by amorphous organic matter $(\mathrm{AOM})$ and degraded plant tissue, with very few identifiable palynomorphs. A quantitative assessment was only performed on the lower and upper samples, counting 300 specimens.

\section{Assemblage KS1}

The lowermost assemblage, KS1 from $1.0 \mathrm{~m}$ height in the measured section (Fig. 2), is dominated by spores constituting c. $60 \%$. The most dominant spores are Deltoidospora spp. and Marattisporites scabratus (Table 1). Other spores that are common include the Osmundacidites wellmannii and Calamospora tener. Among the pollen, Monosulcites minimus, Vitreisporites pallidus, Perinopollenites elatoides and Chasmatosporites hians are the most common. This indicates a vegetation dominated by tree ferns and ground ferns, with scattered bennettittaleans, caytonialeans, ginkgoaleans/cycadaleans and cupressacean trees. The cupressacean trees probably preferred wet mire environments, while the other trees most likely preferred more well-drained areas.
The sample contains large amounts of black phytoclasts and black wood remains. The composition of the palynoflora, together with the absence of freshwater or marine microalgae, suggests a terrestrial depositional environment. This is somewhat surprising as this sample is from the paper shale, which is presumed to represent an open lacustrine/lagoon environment (Dam \& Surlyk 1992, 1993). The dominance of spores suggests a sparsely forested setting, but the abundance of wood fragments and black phytoclasts indicate the presence of forests nearby.

The presence and rare occurrence of Cerebropollenites thiergartii suggest an age not older than Hettangian (Hillebrandt et al. 2013; Mander et al. 2013; Peterffy et al. 2016; Vajda et al. 2016). The general absence of typical Rhaetian taxa that normally linger on into the earliest Hettangian, suggest an age younger than the earliest Hettangian. Only two questionable typical Rhaetian specimens were registered, one possible Granulatisporites rudis and one aberrant specimen of Lunatisporites rhaeticus. Both could also be reworked.

\section{Assemblage KS2}

AOM and poorly preserved plant matter dominate the sample. Palynomorphs are generally poorly preserved. Pinuspollenites minimus appears to be relatively common (Table 1). A specimen of the putative dinoflagellate cyst 'Rotundus granulatus' was registered.

\section{Assemblage KS3}

The spore-pollen flora of the upper sample, from $8.60 \mathrm{~m}$ in the section (Fig. 2), is dominated by Perinopollenites elatoides together with abundant Pinuspollenites minimus (Table 1). Spores have declined in abundances, making up c. $20 \%$ of the spore-pollen flora, with the most abundant taxon being Deltoidospora spp. (Table 1). Other spores such as Trachysporites spp., Conbaculatisporites spinosus, Punctatisporites globosus, Osmundacidites wellmannii and Marattisporites scabratus, are present but not common. Monosulcate pollen assigned to Chasmatosporites spp., Monosulcites punctatus and $M$. minimus are common, as are Classopollis meyerianus. This suggests that a more extensive coastal mire environment had developed, with pinacean conifers occupying drier hinterland areas. Cheirolepidiacean conifers are also believed to have preferred drier habitats, perhaps in the uplands. Tree ferns, bennettittaleans and ginkgoaleans/cycadaleans may have occupied drier patches in the coastal mires.

The putative dinoflagellate cyst 'Rotundus granulatus' comprise $>12 \%$ of the total assemblage (Table 1 ). 
This taxon has been recorded in Rhaetian to Lower Jurassic strata of the Danish Basin (Koppelhus \& Nielsen 1994; Koppelhus \& Batten 1996; Lindström et al. 2017a). It is a granulate, oval to spherical, and often folded palynomorph, which can be difficult to differentiate from folded specimens of, for example Osmundacidites wellmannii in poorly preserved assemblages. In the present samples, the assemblages are well preserved, allowing confident identification of specimens of 'Rotundus granulatus'. Very rarely specimens exhibit poorly developed paratabulation. It has been recorded in both marine and marginal marine strata (Koppelhus \& Nielsen 1994; Koppelhus \& Batten 1996; Lindström et al. 2017a), hence, it is considered to be a cyst of a dinoflagellate which was tolerant of brackish water conditions. Also, a few dinoflagellate cysts of likely marine origin were observed in this sample (Fig. 6). Apart from this, no other marine or freshwater microalgae were recorded in KS3.

Rare specimens of reworked palynomorphs were also recorded in this sample, and include the Permian taxa Cordaitina sp., Lueckisporites virkkiae and Vittatina sp., and the Middle to Late Triassic taxa Granuloperculatipollis rudis, Lunatisporites rhaeticus, Ovalipollis ovalis, Podosporites amicus and Retisulcites perforatus.

\section{Stratigraphical indications}

The recorded spore-pollen assemblages are dominated by long-ranging taxa. The palynofloral composition is rather typical for the Hettangian. The general lack of a variety of Rhaetian markers, specifically Ricciisporites tuberculatus, Ovalipollis ovalis, Lunatisporites rhaeticus, Limbosporites lundbladiae and Cingulizonates rhaeticus that in many NW European sections linger on into the earliest Hettangian (Lindström et al. 2017b), may suggest a younger Hettangian age. The few possible typical Rhaetian taxa registered are also present in older Triassic strata, and because they co-occur in KS3 with reworked middle to early late Triassic and Permian taxa, they are herein considered to also be reworked. In comparison to previously described Hettangian palynofloras from the Kap Stewart Group at Astartekløft and several other localities along the Hurry Inlet (Pedersen \& Lund 1980; Mander et al. 2013), the herein described assemblages are most similar to those reported from Muskusokse-Hareelv by Pedersen \& Lund (1980). Pedersen \& Lund (1980) subdivided their Hettangian Zone 2 into two, a lower and an upper, subzones. The lower subzone was distinguished from the upper one by lacking $C$. thiergartii, while this taxon is regularly present in the upper zone. This could possible indicate that the assemblages investigated herein could correlate with their Upper Zone 2.

\section{Discussion}

The studied succession represents a deltaic system that flanked a large lake (Dam \& Surlyk 1992, 1993). The delta plain was characterized distributary channels as well as interdistributary bays. The lake basin was probably low-lying and close to the open sea (Dam \& Surlyk 1993), and the presence of plesiosaur bones as well as putative dinoflagellate cysts and 'true' dinoflagellate cysts in the studied succession suggest marine influence. Plesiosaurs are predominantly marine animals, but they have on rare occasions been reported in non-marine settings suggesting they could occasionally venture from the ocean into brackish to fresh-water environments (Gao et al. 2019). The presence of plesiosaur skeletal remains and teeth thus represents a marine signal in the middle part of Rhætelv Formation of the Kap Stewart Group. It is possible that the Kap Stewart plesiosaurs migrated seasonally between the sea and the inland lake (cf. Goa et al. 2019). Alternatively, the plesiosaurs could have entered the lake basin during a period of sea-level highstand. Reports of non-marine plesiosaurs are scarce and most of them originate from Cretaceous deposits closely associated with near-shore marine and estuary settings (e.g. Russell 1931; Kear 2006, 2012; Vajda \& Raine 2010; Benson et al. 2013; Sachs et al. 2016, 2017; Gao et al. 2019). Jurassic records of plesiosaurs in nonmarine, settings are reported from the Middle Jurassic of China (Gao et al. 2019), and from fragmentary material from the lower Jurassic (Sinemurian and Toarcian) of Australia (Thulborn \& Warren 1980; Kear 2012). Hybodont sharks are relative common in the Jurassic (e.g. Rees 1998; Rees \& Underwoood 2008). They inhabited rivers, estuaries and lagoons as well as coastal marine environments (Reeds 1998). Their presence in the vertebratebearing fossil bed therefore cannot be used to support marine influence.

The episode of likely marine influence took place in the middle of the deposits covered by the lake system. The age of this marine incursion has been constrained by palynological evidence to the Hettangian, probably middle to late Hettangian age. According to Haq (2017) and Kent et al. (2017) the Hettangian lasted from 201.3 to $199.5 \mathrm{Ma}$ and thus had a duration of about $2 \mathrm{Ma}$.

It is suggested here that the plesiosaur arrived in the basin during a sea-level highstand. Surlyk (1990) 
recorded a middle Hettangian sea-level rise event in the basin (Fig. 6). Hardenbol et al. (1998) define three global highstands (marine flooding surfaces), a minor one in the early Hettangian, followed by a medium and major highstand later in the Hettangian. Haq (2017) describes two highstands during the Hettangian both followed by sea-level drops; amplitudes of these sea-level variations were between 25 and $75 \mathrm{~m}$ (medium scale) or below $25 \mathrm{~m}$ (minor scale). According to Haq (2017), the first highstand occurred immediately before $200.8 \mathrm{Ma}$, while the second highstand occurred immediately before $200 \mathrm{Ma}$ (Fig. 6).

Haq (2017) writes that the identified Jurassic sealevel variations are Eurocentric as they primarily are based on ammonite biostratigraphy in sections of central and northern Europe. Certain identification of contemporaneous highstands in the lowermost Jurassic deposits of central East Greenland is not possible due to the lack of ammonites. With assumed sea-level variation up to $75 \mathrm{~m}$ during the Hettangian it is considered likely, however, that the plesiosaurs arrived in the Jameson Land Basin during one of the two highstands of Haq (2017). As the palynological date indicates a middle to late Hettangian age, it seems likely that the marine incursion in the Jameson Land Basin can be correlated with the highstand that took place immediately before $200 \mathrm{Ma}$ (Fig. 5). Surlyk (1990) also finds a middle Hettangian sea-level rise event. This interpretation of marine-influenced deposits occurring 185$200 \mathrm{~m}$ above the base of the Rhætelv Formation provides an important new numerical age control of this hitherto poorly age-constrained succession.

An additional, and early, episode of marine influence is suggested by the presence of a tooth from a marine shark, Rhomphaiodon minor, approximately $30 \mathrm{~m}$ above the base of the Rhætelv Formation near 'Track Mountain' (Hansen et al. 2016). This shark is known from marine deposits in the Rhaetian of NW Europe (Hansen et al. 2016). It is likely therefore that the Rhaetian-Hettangian (Triassic-Jurassic boundary) is situated somewhere between 30 and $185 \mathrm{~m}$ above the base of the formation. Additional palynological investigation of samples from this interval is required to place the boundary more accurately.

Imprints of brittle stars at the base of the overlying Neill Klinter Group indicate a more permanent connection to the sea. According to Dam \& Surlyk (1998) this transgression was gradual and took place at the Late Sinemurian-Pliensbachian transition, and the basin was flooded though a south-eastern entrance along the present day Scoresby Sund.

Offshore mid-Norway (Halten Terrace) contemporaneous sediments in the Åre Formation (Rhaetian to Early Pliensbachian) formed during an overall transgression (Thrana et al. 2014). The transgression in this area is witnessed by a succession that comprises lowermost non-marine coastal (delta) plain deposits followed by coastal plain deposits with marine influence, estuarine deposits, and at the top open marine shoreface deposits. The transgression was related to the establishment of a seaway between the Tethys Sea in the south and the Boreal Sea in the north (Thrana et al. 2014).

\section{Conclusions}

The sediments of the Rhætelv Formation in the Kap Stewart Group (Rhaetian-Sinemurian) formed in a lake basin flanked by deltas. However, the discovery of plesiosaur bone remains in a thin sandstone bed in the middle part of the Rhætelv Formation at the eastern margin of the Jameson Land Basin suggests a period of marine influence in this otherwise strictly continental basin. A plesiosaur entered the basin during this period and bone remains of this animal were eroded from delta front sediments during a storm and probably transported onshore during an inundation event and deposited in a large interdistributary bay on the delta plain. Palynological data indicates that the marine incursion is of middle to late Hettangian age. By comparison with data on global sea-level variation, it is suggested that the marine incursion took place immediately before $200 \mathrm{Ma}$, and thereby gives a wellconstrained age of the vertebrate-bearing fossil layer in the Rhætelv Formation.

Acknowledgements. - We gratefully acknowledge support from Dronning Margrethes og Prins Henriks Fond, Arbejdsmarkedets Feriefond, Oticon Fonden, Knud Højgaards Fond, Louis Petersens Legat, Det Obelske Familiefond, Ernst og Vibeke Husmans Fond, the Independent Research Fund Denmark, GeoCenter Møns Klint and GEUS. We are grateful to Gregers Dam for discussions on the stratigraphy of the Kap Stewart Group.

\section{References}

Belcher, C.M., Mander, L., Rein, G., Jervis, F.X., Haworth, M., Hesselbo, S.P., Glasspool, I.J. \& McElwain, J.C. 2010: Increased fire activity at the Triassic/Jurassic boundary in Greenland due to climate driven flora change. Nature Geoscience 3, 429.

Benson, R.B.J., Fizgerald, E.M.G. \& Vickers-Rich, P. 2013: Large freshwater plesiosaurian from the Cretaceous (Aptian) of Australia. Alcheringa: An Australian Journal of Palaeontology 37, 456-461.

Clemmensen, L.B. (1976): Tidally influenced deltaic sequences from the Kap Stewart Formation (Rhaetic-Liassic), Scoresby land, East Greenland. Bulletin of the Geological Society of Denmark, 25, 1-13.

Clemmensen, L.B., Kent, D.V., Mau, M., Mateus, O. \& Milàn, J. 2020: Triassic lithostratigraphy of the Jameson Land Basin (central East Greenland), with emphasis on the new Fleming Fjord Group. Bulletin of the Geological Society of Denmark 68, 95-132. 
Dam, G. \& Surlyk, F. 1992: Forced regressions in a large waveand storm-dominated anoxic lake, Rhaetian-Sinemurian Kap Stewart Formation, East Greenland. Geology 20, 749-752.

Dam, G. \& Surlyk, F. 1993: Cyclic sedimentation in a large waveand storm-dominated anoxic lake; Kap Stewart Formation (Rhaetian-Sinemurian), Jameson Land, East Greenland. Special Publications of the International Association of Sedimentologists $18,419-448$.

Dam, G. \& Surlyk, F. 1998: Stratigraphy of the Neill Klinter Group; a Lower-lower Middle Jurassic tidal embayment succession, Jameson land, East Greenland. Geology of Greenland Survey Bulletin 175, 80 .

Gao, T., Li, D.-Q., Li, L.-F. \& Yang, J. 2019: The first record of freshwater plesiosaurian from the Middle Jurassic of Gansu, NW China, with its implications to the local palaeobiogeography. Journal of Palaeogeography 8,8 .

Hansen, B.B., Milàn, J., Clemmensen, L.B., Adolfssen, J.S., Estrup, E.J., Klein, N., Mateus, O. \& Wings, O. 2016: Coprolites from the Late Triassic Kap Stewart Formation, Jameson Land, East Greenland: morphology, classification and prey inclusions. Geological Society, London, Special Publications 434, 49-69.

Haq, B.U. 2017: Jurasic sea-level variation: a reappraisal. GSA Today 28, 7 .

Hardenbol, J., Thierry, J., Farley, M.B., Jacquin, T., De Graciansky, P.C. \& Vail, P.R. 1998: Mesozoic and Cenozoic sequence chronostratigraphic framework of European basins. Society of Economic Paleontologists and Mineralogists Special Publication 60, 3-13.

Hesselbo, S.P., Robinson, S.A., Surlyk, F. \& Piasecki, S. 2002: Terrestrial and marine extinction at the Triassic-Jurassic boundary synchronized with major carbon-cycle perturbation: a link to massive volcanism. Geology 30, 251-254.

Hillebrandt, A.V., Krystyn, L., Kürschner, W.M., Bonis, N.R., Ruhl, M., Richoz, S., Schobben, M.A.N., Urlichs, M., Bown, P.R., Kment, K., McRoberts, C.A., Simms, M. \& Tomãsových, A. 2013: The global stratotype sections and point (GSSP) for the base of the Jurassic System at Kuhjoch (Karwendel Mountains, Northern Calcareous Alps, Tyrol, Austria). Episodes 36, 162-198.

Kear, B.P. 2006: Plesiosaur remains from Cretaceous highlatitude non-marine deposits in Southeastern Australia. Journal of Vertebrate Paleontology 26, 196-199.

Kear, B.P. 2012: A revision of Australias Jurassic plesiosaurs. Palaeontology 55, 1125-1138.

Kent, D.V. \& Clemmensen, L.B. 2021: Northward dispersal of dinosaurs from Gondwana to Greenland at the mid-Norian (215-212 Ma, Late Triassic) dip in atmospheric $\mathrm{pCO}_{2}$. Proceedings of the National Academy of Sciences of the United States of America 118, e2020778118.

Kent, D.V., Olsen, P. \& Muttoni, G. 2017: Astrochronstratigraphic polarity time scale (APTS) for the Late Triassic and Early Jurassic from continental sediments and correlation with standard marine stages. Earth-Science Reviews 166, 153-180.

Koppelhus, E.B. \& Batten, D.J. 1996: Chapter 20C. Appilcation of a palynomorph zonation to a series of short borehole sections, lower to middle Jurassic, Øresund, Denmark. In Jansonius, J. \& McGregor, D.C. (eds): Palynology: Principles and Applications, volume 2, 779-793 pp. American Association of Stratigraphic Palynologists Foundation, Dallas, Texas.

Koppelhus, E.B. \& Nielsen, L.H. 1994: Palynostratigraphy and palaeoenvironemnts of the lower to middle Jurassic Bagå Formation of Bornholm, Denmark. Palynology 18, 139-194.

Lindström, S., Erlström, M., Piasecki, S., Nielsen, L.H. \& Mathiesen, S. 2017a: Palynology and terrestrial ecosystem change of the Middle Triassic to lowermost Jurassic succession of the eastern Danish Basin. Review of Palaeobotany and Palynology 244, 65-95.

Lindström, S., van de Schootbrugge, B., Hansen, K.H., Pedersen, G.K., Alsen, P., Thibault, N., Dybkjær, K., Bjerrum, C.J. \& Nielsen, L.H. 2017b: A new correlation of Triassic-Jurassic boundary successions in NW Europe, Nevada and Peru, and the Central Atlantic Magmatic province: a time-line for the
end-Triassic mass extinction. Palaeogeography, Palaeoclimatology, Palaeoecology 478, 80-102.

Mander, L., Kürschner, W.M. \& McElwain, J.C. 2013: Palynostratigraphy and vegetation history of the Triassic-Jurassic transition in East Greenland. Journal of the Geological Society 170, $37-46$.

Marzola, M., Mateus, O., Milàn, J. \& Clemmensen, L.B. 2018: A review of Palaeozoic and Mesozoic tetrapods from Greenland. Bulletin of the Geological Society of Denmark 66, 21-46.

McElwain, J.C., Beerling, D.J. \& Woodward, F.I. 1999: Fossil plants and global warming at the Triassic-Jurassic boundary. Science 285, 1386-1390.

McElwain, J.C., Popa, M.E., Hesselbo, S.P., Haworth, M. \& Surlyk, F. 2007: Macroecological responses of terrestrial vegetation to climatic and atmospheric change across the Triassic/Jurassic boundary in East Greenland. Paleobiology 33, 547-573.

Milàn, J., Clemmensen, L.B., Adolfssen, J.S., Estrup, E.J., Frobøse, N., Klein, N., Mateus, O. \& Wings, O. 2012: A preliminary report on coprolites from the Late Triassic part of the Kap Stewart Formation, Jameson Land, East Greenland. New Mexico Museum of Natural History and Science Bulletin 57, 203-206.

Milàn, J., Mateus, O., Marzola, M. \& Clemmensen, L.B. 2016: Plesiosaur remains from the Lower Jurassic part of the Kap Stewart Formation, Jameson Land, East Greenland - evidence of the earliest marine incursion. The Palaeontological Association 60th Annual Meeting, 14th-17th December 2016. Programme, Abstracts and AGM papers, 95-96.

Pedersen, K.R. \& Lund, J.J. 1980: Palynology of the plant-bearing rhaetian to Hettangian Kap Stewart formation, scoresby sund, East Greenland. Review of Palaeobotany and Palynology 31, 169.

Petterffy, O., Calner, M. \& Vajda, V. 2016: Early Jurassic cyanobacterial mats - a potential response to reduced biotic activity in the aftermath of the Triassic mass extinction event. Palaeogeography, Palaeoclimatology, Palaeoecology 464, 134132.

Rees, J. (1998): Early Jurassic selachians from the Hasle Formation on Bornholm, Denmark. Acta Palaeontologica Polonica, 43, 439-452.

Rees, J. \& Underwood, C.J. 2008: Hybodont sharks of the English Bathonian and Callovian (middle Jurassic). Palaeontology 51, 117-147.

Russell, L.S. 1931: Fresh-water plesiosaurs. The Canadian FieldNaturalist 45, 135-137.

Sachs, S., Hornung, J.J., Lallensack, J.N. \& Kear, B.P. 2016: Evidence for a Simolestes-like plesiosaurian from the Berriasian (lower Cretaceous) limnic-brackish Bückeberg group of northwestern Germany. In Kear, B.P., Lindgren, J. \& Sachs, S. (eds): Abstracts Volume of the 5th Triennial Mosasaur Meeting - A Global Perspective on Mesozoic Marine Amniotes, 35-37. Uppsala University, Uppsala.

Sachs, S., Hornung, J.J., Lallensack, J.N. \& Kear, B.P. 2017: First evidence of a large predatory plesiosaurian from the lower Cretaceous non-marine 'Wealden facies' deposits of northwestern Germany. Alcheringa 642, 1-8.

Steinthorsdottir, M., Jeram, A.J. \& McElwain, J.C. 2011: Extremely elevated $\mathrm{CO} 2$ concentrations at the Triassic/Jurassic boundary. Palaeogeography, Palaeoclimatology, Palaeoecology 308, 418-432.

Steinthorsdottir, M., Woodward, F.I., Surlyk, F. \& McElwain, J.C. 2012: Deep-time evidence of a link between elevated CO2 concentrations and perturbations in the hydrological cycle via drop in plant transpiration. Geology 40, 815-818.

Steinthorsdottir, M., Elliott-Kingston, C. \& Bacon, K.L. (2018): Cuticle surfaces of fossil plants as a potential proxy for volcanic SO2 emissions: observations from the Triassic-Jurassic transition of East Greenland. Palaeobiodiversity and Palaeoenvironments, 98, 49-69.

Surlyk, F. 2003: The Jurassic of East Greenland: a sedimentary record of thermal subsidence, onset and culmination of rifting. In Surlyk, F. \& Ineson, J.R. (eds): The Jurassic of Denmark and Greenland. Geological Survey of Denmark and Greenland 
Bulletin, 1, 659-722. Geological Survey of Denmark and Greenland (GEUS), Denmark.

Surlyk, F. 1990: A Jurassic sea-level curve for East Greenland. Palaeogeography, Palaeoclimatology, Palaeoecology 78, $71-85$.

Surlyk, F., Alsen, P., Bjerager, M., Dam, G., Engkilde, M., Hansen, C.F., Larsen, M., Noe-Nygaard, N., Piasecki, S., Therkelsen, J. \& Vosgerau, H. 2021: Jurassic stratigraphy of East Greenland. GEUS Bulletin 46, 1-116.

Surlyk, F., Callomon, J.H., Bromley, R.G. \& Birkelund, T. 1973: Stratigraphy of the Jurassic - lower Cretaceous sediments of Jameson Land and Scoresby Land, East Greenland. Bulletin Grønlands Geologiske Undersøgelse 105, 76.
Thrana, C., Næss, A., Leary, S., Gowland, S., Brekken, M. \& Taylor, A. 2014: Updated depositional and stratigraphical model of the Lower Jurassic Are Formation, Heidrun Field, Norway. International Association of Sedimentologists, Special Publication 46, 253-290.

Thulborn, R.A. \& Warren, A. 1980: Early Jurassic plesiosaurs from Australia. Nature 285, 224-225.

Vajda, V., Linderson, H. \& McLoughlin, S. 2016: Disrupted vegetation as a response to Jurassic volcanism in southern Sweden. Geological Society, London, SpecialPublication 434, 127-147.

Vajda, V. \& Raine, J.I. 2010: A palynological investigation of plesiosaur-bearing rocks from the Upper Cretaceous Tahora Formation, Mangahouanga, New Zealand. Alcheringa 34, 359-374. 